\title{
Perkembangan Islam di tengah Fenomena Islamofobia di Jerman
}

\author{
Muhammad Wildan \\ (UIN Sunan Kalijaga, Yogyakarta, Indonesia; wildan71@gmail.com)
}

\begin{abstract}
Although Islam in Europe is not a new phenomenon, Muslims in Germany are still quite remarkable to study. The dynamic of Muslims both internally and externally is the most interesting thing. Internally, Muslims in Germany who are coming from many different ethnics and races in Asia and Africa is a such a big challenge for Muslims to unite and integrate. Externally, Islam which is historically not a "homegrown" religion in Europe is facing such a big challenge to adjust to such a "new" circumstances. Judeo-Christian has long been the cultural tradition of Germans and Europeans in general. The influx of a number of Muslims from some conflict areas in the Middle East and Africa recently adds another notable phenomenon. This article is trying to portray the development of Islam and Muslims in Germany and the way how they mingle with German counterparts along with the growing of islamophobia in the country. Eventually, this article will also observe some resistance of Muslims in the form of radicalism in the country and their efforts to integrate into Western society.
\end{abstract}

Keywords: Islamic history, population, Islamophobia, discrimination, integration.

\begin{abstract}
Abstrak
Meskipun Islam di Eropa bukanlah fenomena baru, Muslim di Jerman masih cukup luar biasa untuk dipelajari. Dinamika umat Islam baik secara internal maupun eksternal adalah hal yang paling menarik. Secara internal, Muslim di Jerman yang berasal dari berbagai etnis dan ras di Asia dan Afrika merupakan tantangan besar bagi umat Islam untuk bersatu dan berintegrasi. Secara eksternal, Islam yang secara historis bukan agama "asli" di Eropa menghadapi tantangan besar untuk menyesuaikan diri dengan keadaan "baru" tersebut. Yahudi-Kristen telah lama menjadi tradisi budaya Jerman dan Eropa pada umumnya. Masuknya sejumlah Muslim dari beberapa daerah konflik di Timur Tengah dan Afrika baru-baru ini menambah fenomena penting lainnya. Artikel ini mencoba menggambarkan perkembangan Islam dan Muslim di Jerman dan cara mereka bergaul dengan rekan-rekan Jerman seiring dengan tumbuhnya islamofobia di negara ini. Akhirnya, artikel ini juga akan mengamati beberapa perlawanan umat Islam dalam bentuk radikalisme di negara itu dan upaya mereka untuk berintegrasi ke dalam masyarakat Barat.
\end{abstract}

Kata kunci: Sejarah Islam, populasi, Islamofobia, diskriminasi, integrasi. 


\section{ARTIKEL}

E-ISSN: $2615-5028$

\section{A. Pendahuluan}

Walaupun secara kultural Jerman bukan "rumah" bagi Islam, agama ini berkembang dengan pesat di Jerman dan juga Eropa Barat secara umum. Populasi Muslim di Jerman yang saat ini merupakan terbesar kedua di Eropa Barat setelah Perancis akan terus bertambah seiring dengan kehadiran para imigran dari berbagai belahan dunia, khususnya Turki dan negara-negara di Timur Tengah yang sedang mengalami konflik. Pada awalnya, pemerintah Jerman pada tahun 1960-an sengaja mendatangkan tenaga imigran dari sejumlah negara untuk membangun perekonomian Jerman pasca Perang Dunia II. Para imigran ini kemudian menjadi buruh di sejumlah kota-kota industri dan lebih memilih untuk tetap tinggal di Jerman daripada kembali ke negeri asalnya. Oleh sebab itu, tidak aneh kiranya jika saat ini sebagian politikus Jerman menganggap Jerman sebagai negeri para imigran.

Saat ini populasi Muslim di Jerman telah mencapai sekitar 5 juta jiwa $(6,1 \%)^{1}$ dan menjadi agama terbesar kedua setelah Kristen. Walaupun secara umum bisa dikatakan bahwa Muslim di Jerman bisa beradaptasi di lingkungan bertradisi YahudiKristen, Muslim di Jerman tidak berarti tidak menghadapi masalah. Selain secara internal umat Islam mereka mengalami banyak masalah, Muslim di Jerman juga mengalami sejumlah perlakuan diskriminatif di ranah sosial seiring dengan merebaknya islamofobia dan ekstrem kanan Kristen di Eropa Barat. Tulisan ini akan membahas tentang sejarah Islam di Jerman, beberapa permasalahan kontemporer juga akan dibahas seperti pengakuan resmi terhadap Islam dari pemerintah,

1 http://www.pewresearch.org/fact-tank/2016/07/19/5-facts-about-the-muslim-population-ineurope/ (diakses 27 Maret 2019). 


\section{ARTIKEL}

E-ISSN: $2615-5028$

diskriminasi di tempat kerja, diskriminasi pemakai bijab, kesulitan integrasi, dan radikalisme agama.

\section{B. Metode}

Penelitian ini didasarkan pada paradigma metode penelitian kualitatif dengan analisis deduktif. Pendekatan penelitian ini dipilih karena mencakup penggalian materi secara mendalam. ${ }^{2}$ Demikian karena tujuan dari penelitian ini sesuai dengan tujuan metode kualitatif, yaitu untuk memahami keadaan, peristiwa, kelompok, atau interaksi sosial tertentu. ${ }^{3}$ Studi ini melalui proses investigasi di mana peneliti secara bertahap memahami fenomena sosial dengan membedakan, membandingkan, mereproduksi, membuat katalog, dan mengklasifikasikan obyek penelitian. ${ }^{4}$ Penelitian seperti ini melibatkan peneliti untuk mempelajari setting alamiah, walaupun pendekatannya bersifat kontekstual.

\section{Hasil dan Pembahasan}

\section{Sejarah Islam di Jerman}

Republik Federal Jerman merupakan salah satu negara besar di Eropa Barat dan menjadi jantung bagi negara-negara di Eropa. Sejak tahun 2005 Jerman dipimpin oleh Kanselir Angela Merkel dan merupakan kanselir wanita pertama dalam sejarah pemerintahan negara Jerman. Pada 2018 populasi Jerman diperkirakan mencapai 83 juta jiwa dan menjadi negara dengan jumlah penduduk terbanyak di Uni Eropa, serta

${ }^{2}$ Davidson, Emma, Rosalind Edwards, Lynn Jamieson, and Susie Weller. "Big data, qualitative style: a breadth-and-depth method for working with large amounts of secondary qualitative data." Quality \& Quantity 53, no. 1 (2019): 363-376.

${ }^{3}$ Fink, Arlene. Conducting research literature reviews: from the Internet to paper. Sage Publications, 2019.

${ }^{4}$ Salganik, Matthew J. Bit by bit: social research in the digital age. Princeton University Press, 2019. 
negara nomor 2 untuk tujuan imigran setelah Amerika. Adapun komposisi masyarakat Jerman sebagian besar merupakan penduduk asli Jerman $(80,8 \%)$, disusul etnis Eropa lainnya sekitar 11,7\%, dan non-Kaukasian seperti Turki (3,4\%) dan Arab $(1,3 \%) .{ }^{5}$ Dalam bidang agama, berdasarkan sensus 2011 sekitar 66,8\% penduduk Jerman berafiliasi ke agama Kristen (Protestan 31,7\% dan Katolik Roma 31,2\%) dan Ateis $33 \%$.

Islam di Jerman mempunyai sejarah yang panjang bahkan sejak zaman Turki Usmani. Ketika Turki Usmani menginvasi Wina (Austro-Hungaria) pada tahun 1683, banyak tentara Turki yang dipenjara di wilayah kerajaan Prussia (sekarang Jerman). Sejak saat itu, komunitas Muslim di wilayah Jerman sudah ada dan terus berlanjut hingga abad berikutnya. Kedatangan umat Islam gelombang berikutnya di wilayah Jerman adalah pada abad ke-18 ketika Raja Friedrich Willem I Kerajaan Prussia menjalin hubungan kerja sama dengan Dinasti Turki Usmani dalam bidang militer. Turki Usmani mengirim sejumlah tentara ke Prussia untuk belajar militer. Sebagai bentuk penghormatan terhadap kehadiran tentara Muslim Turki, pada tahun 1732 Raja Friedrich Wilhelm I membangun sebuah masjid di Potsdam, kota di Bundesland Brandenburg, sebagai tempat beribadah mereka. ${ }^{6}$

Hubungan kerja sama dalam bidang militer antara kedua kerajaan ini tetap berlanjut pada masa pemerintahan berikutnya, yaitu Raja Friedrich II (1740-1786). Pada tahun 1945, Raja Friedrich II membentuk unit Muslim pada tentara Prussia yang disebut dengan nama "Muslim Riders" yang terdiri 1.000 orang dari Muslim etnis Bosnia, Albania, dan Tatar. Pada tahun 1798, sebuah kuburan Muslim dibangun

5 Statistisches Bundesamt (Destatis), 2017. (diakses 7 Maret 2019)

${ }^{6}$ Joel S. Fetzer \& J. Christopher Soper. Muslims and the State in Britain, France and Germany. (Cambridge University Press: Cambridge. 2005), 99. 


\section{ARTIKEL}

di Berlin sebagai penghormatan terhadap Duta Besar Turki ke-3 Ali Aziz Efendi dan pada tahun 1980-an dibangun sebuah masjid di sampingnya dengan nama masjid Sehitlik (Turki: syahid).

Memasuki permulaan abad ke-20, hubungan Jerman dan Turki Usmani semakin erat. Pada tahun 1912, Enver Pasha, Menteri Peperangan Turki Usmani menjalin kerja sama dengan Jerman untuk mengirimkan sejumlah diplomat dan perwira Jerman untuk melatih para tentara Turki Usmani. ${ }^{8}$ Setelah Perang Balkan (1912-1913) berakhir, Turki terlibat dalam Perang Dunia I (1914-1918) dan menjadi sekutu Jerman. Dalam perang tersebut pihak Jerman mengalami kekalahan dan banyak tentara dari Turki Usmani yang menjadi tawanan perang dan memilih untuk menetap di Jerman, khususnya di Berlin, dari pada kembali ke negeri asalnya, Turki. ${ }^{9}$ Pada tahun 1922, sejumlah Muslim dari 44 etnis membangun komunitas Muslim di Berlin walaupun akhirnya mereka gagal mendirikan masjid karena masalah finansial. Masjid pertama di Jerman baru kemudian dibangun oleh komunitas Ahmadiyah (Lahore) pada tahun $1925 .{ }^{10}$ Ratusan ribu tentara Turki Usmani kembali didatangkan ke Jerman pada masa kepemimpinan Nazi untuk membantu Jerman dalam Perang Dunia II. Dalam perang ini Jerman menderita kekalahan yang mengakibatkan hancurnya perekonomian Jerman.

Pasca Perang Dunia II, khususnya dekade 1960-1970-an, gelombang pekerja imigran dari Turki, Afrika Utara, dan bekas Yugoslavia, mulai didatangkan untuk

${ }^{7}$ https://www.beautifulmosque.com/Sehitlik-Mosque-Berlin-Germany (diakses pada 8 Maret 2017).

${ }^{8}$ Irfan Firdaus, "Peradaban Islam Turki Modern: Dari Westernisasi hingga Sekularisasi" dalam Siti Maryam dkk. Sejarah Peradaban Islam dari Masa Klasik Hingga Modern, (Yogyakarta: LESFI, 2009), 152.

${ }^{9}$ M. Ali Kettani, Minoritas Muslim di Dunia Dewasa Ini, (Jakarta: PT Raja Grafindo Persada, ), 55.

10 Berbeda dengan komunitas Ahmadiyah Qodiyan yang berkembang dengan pesat di Jerman, komunitas Ahmadiyah Lahore cenderung menurun dengan drastis. Jamaah masjid ini mayoritas bukan dari komunitas Ahmadiyah Lahore, tapi masyarakat Muslim di sekitar Berlin. 
membantu pembangunan infrastruktur di Jerman. Walaupun pada awalnya mayoritas adalah laki-laki, pada tahap berikutnya mereka bisa membawa keluarga mereka. ${ }^{11}$ Sejak 1980-an, jumlah imigran Muslim pencari suaka di Jerman mulai meningkat, terutama etnik Turki (Kurdi, Yezidis, dan Asyur). Mayoritas Muslim Turki di Jerman saat ini adalah generasi ke-3 dan ke-4 yang lahir di Jerman, walaupun tidak semuanya sebagai warganegara Jerman. Di samping itu, komunitas Muslim asal Iran dianggap paling bisa berintegrasi di Jerman karena jumlah akademisi dan pebisnis terus meningkat di atas rata-rata. ${ }^{12}$ Karena sejarah Islam di negara cukup panjang, tidaklah mengherankan bila Angela Merkel mengatakan bahwa "Islam adalah bagian dari Jerman". ${ }^{13}$

Gelombang Muslim terakhir yang datang ke Jerman berasal dari kawasan konflik Timur Tengah dan Afrika pada periode 2010-2016. Konflik yang berkepanjangan di Timur Tengah dan Afrika karena Arab Spring dan ISIS telah menyebabkan banyaknya migran dan pencari suaka politik ke negara-negara maju di Eropa Barat. Walaupun sebagian korban konflik di Timur Tengah dan Afrika juga mencari migrasi dan mencari suaka politik ke negara-negara makmur di Timur Tengah, namun sebagian besar menjadikan Eropa Barat sebagai tujuan mereka. Di Eropa Barat, beberapa negara "membuka" diri untuk menerima migran dari negaranegara konflik tersebut seperti Belanda, Norwegia, Austria, Jerman dll. Di Jerman, Angela Merkel menerima lebih dari 1 juta migran yang mayoritas Muslim dengan tangan terbuka. Kebijakan dan sikap kemanusiaan ini tidak luput dari kritik dari berbagai politisi di negara Uni Eropa paling makmur ini. Walaupun demikian,

11 http://www.euro-islam.info/country-profiles/germany/ (diakses 27 Maret 2019)

12 Kettani, Minoritas Muslim, 55.

${ }^{13}$ https://www.dw.com/en/merkel-islam-is-a-part-of-germany/av-43067794 (diakses 7 Maret 2019) 


\section{ARTIKEL}

E-ISSN: $2615-5028$

sebagian kelompok khawatir bahwa jumlah Muslim akan terus bertambah dan menjadi 20 juta Muslim di tahun 2020. ${ }^{14}$

\section{Populasi dan Demografi Muslim}

Secara historis, Muslim datang ke Jerman dalam beberapa gelombang dan populasinya terus meningkat secara signifikan di negara terluas di Eropa Barat itu. Di samping faktor imigran Muslim, faktor lain yang memengaruhi meningkatnya populasi Muslim di negara ini adalah suburnya angka kelahiran bayi dari keluargakeluarga Muslim yang sudah menetap di Jerman dan masuk Islamnya (konversi) sebagian dari orang asli Jerman (Kaukasian).

Terkait dengan perkembangan jumlah populasi Muslim ini, Houssain Kettani menyajikan data populasi Muslim di Jerman dari tahun 1920 sampai dengan 2009 di bawah ini: ${ }^{15}$

Tabel 1: Pertumbuhan Populasi Muslim

\begin{tabular}{|c|c|r|c|}
\hline NO & TAHUN & \multicolumn{1}{|c|}{ POPULASI } & PERSENTASE \\
\hline 1. & 1920 & 1.000 & $0,01 \%$ \\
\hline 2. & 1951 & 20.000 & $0,03 \%$ \\
\hline 3. & 1971 & 1.150 .000 & $1,5 \%$ \\
\hline 4. & 1981 & 1.800 .000 & $2,9 \%$ \\
\hline 5. & 1991 & 2.500 .000 & $3,1 \%$ \\
\hline 6. & 2001 & 3.200 .000 & $3,9 \%$ \\
\hline 7. & 2009 & 4.300 .000 & $5,22 \%$ \\
\hline
\end{tabular}

${ }^{14}$ https://www.gatestoneinstitute.org/6793/germany-20-million-muslims (diakses 27 Muslim 2019).

15 Houssain Kettani, "Muslim Population in Europe: 1950 - 2020" dalam International Journal of Environmental Science and Development, Vol. 1, No. 2, (June 2010), 167. 


\section{ARTIKEL \\ E-ISSN: $2615-5028$}

Selain itu, Pew Research Center juga memprediksikan bahwa jumlah Muslim di Jerman yang saat ini berjumlah 5 juta $(6,1 \%)$ akan terus mengalami peningkatan mencapai angka sekitar 5.545.000 (7,1\%) Muslim pada tahun 2030. ${ }^{16}$ Angka ini belum termasuk imigran yang terus berdatangan karena Jerman merupakan destinasi No. satu untuk imigran. Pada saat yang sama, badan statistik populasi dunia memperkirakan bahwa populasi masyarakat Jerman akan terus mengalami penurunan karena semakin berkurangnya jumlah bayi yang lahir di Jerman dibanding penduduk yang meninggal. Rata-rata angka kelahiran di Jerman berkisar 8,7 sampai dengan 9,8 anak yang lahir per seribu orang. Hal ini berbanding terbalik dengan angka kematian yang berkisar antara 11,6 sampai dengan 15,8 jiwa per seribu orang. Adapun jumlah imigran yang datang ke Jerman diperkirakan tetap akan mengalami pertumbuhan sampai tahun 2050 mendatang. ${ }^{17}$

Migration Police Institute (2011) memberikan data yang menarik terkait imigran di Jerman. Berdasarkan penelitiannya, jumlah imigran di Jerman, baik pendatang baru maupun keturunan, mencapai angka 16 juta jiwa atau seperlima dari 82 juta penduduk Jerman. Sepertiga dari jumlah imigran ini merupakan warga keturunan yang dilahirkan di Jerman. Di sejumlah negara bagian, tercatat bahwa jumlah anak keturunan imigran di bawah usia 10 tahun meningkat sampai dengan 35\%. Di beberapa kota metropolitan seperti Berlin, Hamburg, Frankfurt, Augsburg atau Nurmberg lebih dari 60\% anak yang masuk sekolah pada tahun 2011 merupakan keturunan imigran. ${ }^{18}$

16 Brian J. Grims dan Mehtab S. Karim, The Future of the Global Muslim Population: Projections for 20102030 (Washington: Pew Research Center, 2011), 124.

17 http://www.worldpopulationstatistics.com/germany-population/ (diakses 6 Maret 2015).

18 Nayka Foroutan, Identity and Muslim Integration in Germany (Washington DC: Migration Policy 


\section{ARTIKEL}

E-ISSN: $2615-5028$

Dari 10,6 juta warga pendatang di Jerman sejak tahun 1950, 70,6\% berasal dari luar negara-negara Eropa, 32,3\% dari negara anggota Uni Eropa, 16,4\% dari Asia. Populasi Muslim terbesar berasal dari Turki yang jumlahnya mencapai 2,9 juta (2011) dan kemudian dari kawasan Timur Tengah yang berjumlah kurang lebih 400 ribu jiwa. Komunitas Muslim terbesar kedua adalah keturunan Bosnia dan Herzegovina, yang diikuti oleh Iran, Maroko, Afghanistan, Libanon, Pakistan, syria, Tunisia, Algeria, dan Indonesia. ${ }^{19}$ Adapun komposisi populasi warga pendatang Muslim di Jerman pada tahun 2008 adalah sebagai berikut: ${ }^{20}$

Tabel 2: Komposisi Populasi Pendatang Muslim (2008)

\begin{tabular}{|l|c|}
\hline \multicolumn{1}{|c|}{ ETNIK } & PROSENTASE \\
\hline Turki & $63,2 \%$ \\
\hline Eropa Tenggara & $13,6 \%$ \\
\hline Timur Tengah & $8,1 \%$ \\
\hline Afrika Utara & $6,9 \%$ \\
\hline Asia Selatan \& Tenggara & $4,6 \%$ \\
\hline Iran & $1,7 \%$ \\
\hline Afrika & $1,5 \%$ \\
\hline Asia Tengah & $0,4 \%$ \\
\hline
\end{tabular}

Sekitar 80\% dari populasi Muslim di Jerman masih berstatus sebagai warga pendatang, dan sekitar $608.000(20 \%)$ adalah warga negara Jerman. ${ }^{21}$ Lagi-lagi angka ini akan terus berubah seiring dengan datangnya migran dari daerah-daerah konflik di Timur Tengah dan Afrika.

Institute, 2013), 2.

${ }^{19} \mathrm{http://www.euro-islam.info/country-profiles/germany/} \mathrm{(diakses} 28$ Maret 2019)

${ }^{20}$ Foroutan, Identity and Muslim, 4.

${ }^{21}$ http://www.euro-islam.info/country-profiles/germany/ (diakses 23 Juni 2014) 


\section{ARTIKEL}

E-ISSN: $2615-5028$

Jika lebih diperinci lagi komunitas Muslim Turki yang berada di Jerman kebanyakan berasal dari etnis Turki dan Kurdi yang sebagian besar sudah terpengaruh oleh paham pembaharuan Kemalis $^{22}$ sehingga lebih mudah dalam menerima nilai-nilai Barat, khususnya budaya Jerman. Crisis Group Europe mencatat bahwa pada tahun 1961, sebanyak seratus dari seribu tenaga kerja imigran di Jerman didatangkan dari Turki yang kebanyakan berasal dari bagian barat daya Anatolia. Pada dekade 1970-an, ketika perekonomian Jerman terus merangkak naik jumlah tenaga kerja imigran ini pun semakin bertambah banyak hingga mendekati angka satu juta tenaga kerja. Sebagian besar komunitas Muslim di Jerman menempati kota-kota besar seperti Berlin, Cologne, Frankfurt, Stutgart, Munich, Lower Saxony, Rheinland Pfalz, Scleswig Holstein, Bremen, dan Hamburg. ${ }^{23}$

\section{Corak Keagamaan dan Organisasi Islam di Jerman}

Muslim di Jerman terdiri berbagai mazhab dan aliran. Sekitar 65\% dari seluruh umat Islam di Jerman merupakan penganut mazhab Sunni, 12\% Syiah-Alawiyah, 7\% Syiah-Yazidiyah, 2\% Syiah-Turki, 1,7\% Ahmadiyah, 0,3\% Ibadi, 0,1\% mistik, 4,0\% aliran lainnya termasuk Syiah Imamiyah dan Ismailiyah. Komunitas Syiah Alawiyah merupakan komunitas agama yang menyatukan berbagai ajaran dari Islam, Kristen, dan Samanisme. ${ }^{24}$ Aliran ini sebagian besar berasal dari daerah Turki di mana pengikutnya berkisar antara $10-30 \%$ dari populasi Turki. ${ }^{25}$ Adapun Syi'ah Ismailiyah terkonsentrasi di sejumlah kota yaitu Essen, Frankfurt, Munich, dan Hamburg. Essen

22 ICG, Islam and Identity in Germany, Europe Report No 181, (14 Maret 2007), 1.

${ }^{23}$ ICG, Islam and Identity, 19.

${ }^{24}$ ICG, Islam and Identity, 19.

${ }^{25}$ ICG, Islam and Identity, 2. 


\section{ARTIKEL \\ E-ISSN: $2615-5028$}

menjadi pusat Syiah Ismailiyah yang dianut oleh para imigran dan keturunan Afganistan. Di kota itu mereka mendirikan masjid Jamaah Khana sebagai tempat ibadah dan merayakan hari-hari besar agama Islam Syiah serta terdapat juga madrasah Baitul Ilmi sebagai lembaga pendidikan bagi anak-anak mereka. ${ }^{26}$

Sebagaimana banyak berkembang di berbagai negara, Salafi juga tumbuh dan berkembang di Jerman. Data pengikut Salafi yang bisa dilacak di Jerman adalah sekitar 3.800 pada 2011 dan meningkat hingga 10.300 pada 2017. Menurut Badan Federal untuk Pendidikan Kewarganegaraan (Bundeszentrale für Politische Bildung) gerakan Salafi berpusat di wilayah Frankfurt Rhine-Main, North Rhine-Westphalia, dan Berlin. Di tahun 2016 dilaporkan bahwa jumlah masjid berafiliasi ke Salafi di North Rhine-Westphalia telah berkembang dari 30 menjadi $55 .{ }^{27}$ Pada February 2017, Asosiasi Masjid Berlin Fussilet (Berliner Fussilet-Moscheeverein) telah dilarang karena salah satu anggotanya Anis Amri, adalah pelaku serangan truk di Berlin pada 2016. Kasus yang sama juga terjadi, organisasi Muslim Deutschsprachige Islamkreis Hildesheim juga dilarang karena beberapa anggotanya disinyalir akan pergi ke wilayah konflik Syria.

Saat ini umat Islam di Jerman memiliki kurang lebih 2.500 masjid dan 140 di antaranya dilengkapi dengan kubah dan menara. Masjid-masjid tersebut dibangun atas inisiatif umat Islam sendiri dan dibantu oleh pemerintah daerah. Adapun masjid pertama di Jerman dibangun oleh Ahmadiyah (Lahore) pada tahun 1924 di Berlin. Walaupun umat Islam sangat beragam dari sisi etnis, mazhab, dan alirannya, secara

26 Yahia Baiza, "Religion, Language or Ethnicity? Hybridized Identity among the Ismaili Youth of Afghanistan in Germany" dalam Fauzia Ahmad dan Siddique Seddon (ed.), Muslim Youth: Challenges, Oppotunities, and Expectacions (London: Continuum, 1998), 28-29.

27 https://rp-online.de/nrw/panorama/nrw-salafisten-agitieren-in-55-moscheen aid-18340503 (diakses 28 Maret 2019). 
umum bisa dikatakan bahwa umat Islam di Jerman sangat berkelompok secara etnis dan mazhab. Hal ini terlihat dengan jelas pada adanya beberapa organisasi Islam dan masjid yang secara umum dibangun oleh komunitas berdasarkan etnis dan mazhab. Beberapa organisasi Islam di Jerman, antara lain:

1. Verband der Islamischen Kulturzentren (Persatuan Pusat Kebudayaan Islam, VIKZ). VIKZ merupakan komunitas keagamaan tertua di Jerman yang berdiri pada tahun 1973. Organisasi ini merupakan komunitas Sufi yang terdiri lebih dari 100.000 anggota, dengan program pelatihan Imam, kursus baca Alquran, dan kursus Syariah. VIKZ memiliki 300 cabang di seluruh Jerman dan 160-250 tempat ibadah. Organisasi ini berhubungan erat dengan gerakan tarekat Sufi Sulayman (1888-1959) dan menjadi gerakan terkemuka pada dekade 1920-an dan 1930-an. Meski tidak berhubungan dengan partai atau gerakan Islam tertentu dan pemerintahan, sejumlah masjid di bawah naungan VIKZ aktif berpartisipasi dalam acara "Day of Open Mosque" di beberapa kota. ${ }^{28}$

2. Diyanet I'leri Turk-Islam Birli'i (Turkish Islamic Union for Religious Affairs, DITIB). DITIB merupakan organisasi Islam terbesar yang mewakili Muslim Turki di Jerman. Organisasi ini tidak hanya ada di Jerman, tetapi juga di sejumlah negara Eropa yang terdapat komunitas Muslim Turki. Cabang DITIB di Jerman berdiri pada tahun 1984 di kota Berlin. Setelah dua tahun berdiri, yaitu pada 1986, lebih dari 250 organisasi Islam masyarakat Muslim Turki di Jerman bergabung di bawah payung organisasi ini. Saat ini lebih dari 300 organisasi Islam dan 800-900 tempat

${ }^{28} \mathrm{ICG}$, Islam and Identity, 10. 


\section{ARTIKEL}

ibadah berada di bawah kontrol DITIB, termasuk menyelenggarakan pengajaran agama Islam di sekolah-sekolah publik. Beberapa tugas DITIB yaitu melayani pengurusan visa, izin imam, izin konstruksi masjid, guru agama, dan pelatihan bahasa Jerman. ${ }^{29}$ DITIB dikenal sebagai organisasi Islam yang moderat. Ajaran Islam yang dibawa organisasi ini merupakan Islam pembaharuan Kemalis. DITIB sudah beberapa kali mengajukan diri ke pemerintah Jerman agar diakui sebagai lembaga yang mewakili seluruh komunitas Muslim di Jerman. Namun, hal itu belum diterima oleh pemerintah Jerman karena keanggotaan organisasi ini hanya terbatas pada masyarakat Turki saja. ${ }^{30}$

3. Islamische Gemeinschaft Milli Gorus (Komunitas Islam Milli Gorus, IGMG). IGMG berdiri pada tahun 1985 dan merupakan kompetitor DITIB. Organisasi ini memiliki hubungan yang dekat dengan partai Islamist di Turki. Anggota dari organisasi ini sekitar 26.500 anggota dan 400-600 tempat ibadah serta mendirikan sekolah-sekolah Alquran, mengorganisir masjid, dan Haji. ${ }^{31}$ Secara umum, para pemimpin dan anggota IGMB berintegrasi dengan baik dengan masyarakat Jerman. Mereka menggunakan bahasa Jerman dan sadar akan hak-haknya, meski berusaha untuk menciptakan masyarakat yang islami. Di Eropa organisasi ini memiliki 14 cabang dan memiliki cita-cita untuk mendirikan Negara Islam

\footnotetext{
${ }^{29}$ ICG, Islam and Identity, 7-8. Lihat juga http://www.euro-islam.info/country-profiles/germany/

${ }^{30}$ ICG, Islam and Identity, 7-8.

${ }^{31}$ I ICG, Islam and Identity, 10.
} 


\section{ARTIKEL}

E-ISSN: $2615-5028$

Turki. Organisasi ini diyakini melakukan cuci otak kepada generasi muda dengan memberi pemikiran Islamist dan anti Barat. ${ }^{32}$

4. Zentralrat der Muslime in Deutschland (Dewan Pusat Muslim, ZMD). ZMD merupakan organisasi Islam di Jerman yang berdiri pada tahun 1994. ZMD dipimpin oleh Ayyup Axel Kohler yang anggotanya berada di delapan negara bagian di Jerman. Dana organisasi ini didapatkan dari Liga Muslim dari Saudi Arabia dan memiliki hubungan dengan Ikhwanul Muslimin. Organisasi ini menaungi sekitar 400 tempat ibadah dan 18 organisasi keagamaan. Adapun anggota dari ZMD berjumlah antara 12.000 sampai 20.000 anggota. $^{33}$

Di samping beberapa organisasi tersebut, terdapat juga organisasi payung yang menyatukan organisasi-organisasi Muslim yang lebih besar, antara lain:

1. Islam Council/Islamrat (IR). IR berdiri pada tahun 1986 di Berlin dan menaungi 23 organisasi Islam. Jumlah anggota organisasi ini sekitar 140.000 orang yang didominasi oleh anggota IGMG. Pemimpin IR diberi gelar "Syaikhul Islam", nama pemimpin tertinggi umat Islam pada masa dinasti Turki Usmani. Organisasi ini berpusat di Cologne dan mengontrol 700 tempat ibadah dan 15 organisasi Islam regional (fifteen regional organizations) yang disebut Federasi Islam, termasuk Islamische Gemeinschaft Deutschland di Munich yang berafiliasi dengan Ikhwanul Muslimin. IR merupakan organisasi Islam yang mendukung suatu varian Islam konservatif. IR terus berupaya untuk mendapatkan pengakuan secara

\footnotetext{
${ }^{32}$ ICG, Islam and Identity, 10.

${ }^{33}$ ICG, Islam and Identity, 7-8. 


\section{ARTIKEL}

E-ISSN: $2615-5028$

hukum dari negara dan mendapatkan izin memberikan pengajaran agama Islam di sekolah publik. ${ }^{34}$

2. Dewan Koordinasi Muslim/Koordinationsrat der Muslime (KRM). KRM didirikan pada tahun 2007 oleh DITIB, VIKZ, dan ZMD sebagai organisasi yang membicarakan masalah integrasi Muslim di Jerman. KRM dibentuk bertujuan untuk menjadi organisasi payung bagi semua organisasi Islam di Jerman karena sesuai dengan aturan pemerintah Jerman bahwa pemerintah akan mengakomodir kepentingan seluruh Muslim di Jerman yang tergabung dalam satu wadah organisasi, bukan terpecah dalam berbagai organisasi.

\section{Kebebasan Beragama \& Diskriminasi Muslim di Jerman}

Secara konstitusi, hubungan agama dan negara di Jerman dijamin oleh Grundgesetr, undang-undang dasar yang dibentuk tahun 1949. Dalam hal ini, Grundgesetz, memiliki dua fungsi: di satu sisi memberikan jaminan terhadap peran agama dengan menghargai keyakinan bagi pemeluknya sebagai warga negara, yaitu menjamin hak asasi individu untuk mendapatkan perlakuan yang sama untuk tidak mendapatkan sikap diskriminasi berdasarkan agama. Di sisi yang lain, aturan konstitusi dalam menentukan hubungan negara dengan berbagai komunitas agama yang ada di negara Jerman. Salah satu bagian dari kebebasan beragama ini menyangkut juga dengan kebebasan individu untuk tidak terikat dalam salah satu agama tertentu atau tidak bertuhan. Kebebasan beragama ini tidak hanya berlaku bagi

${ }^{34}$ ICG, Islam and Identity, 10. 


\section{ARTIKEL}

warga Jerman saja, tetapi juga bagi semua orang yang hidup di negara tersebut. Selain itu, masing-masing komunitas agama juga berhak memberikan pendidikan agama sebagai salah satu hak dasar bagi warga negara. ${ }^{35}$

Meskipun Islam adalah agama dengan pengikut terbesar kedua setelah Kristen, Muslim di Jerman masih banyak yang mendapatkan perlakuan diskriminatif di berbagai ranah sosial-budaya, media, hingga politik. Ini membuktikan bahwa Islamofobia masih cukup berkembang di negara di mana kebebasan beragama dilindungi oleh konstitusi dan Piagam Hak-hak Fundamental (Charter of Fundamental Rights). Diskriminasi yang paling umum dan banyak terjadi sebagaimana di negaranegara Uni Eropa lainnya adalah masalah jilbab. Isu jilbab masih menjadi perdebatan di pemerintahan pusat Jerman. Separuh dari 16 negara-negara bagian di Jerman melarang pemakaian simbol-simbol semua agama, yaitu Baden-Württemberg, Bavaria, Berlin, Bremen, Hesse, Lower Saxony, North Rhine-Westphalia, and Saarland. ${ }^{36}$ Sebagai contoh, negara bagian Berlin, Brandenburg, dan Hesse menerapkan "hukum netral" dengan melarang guru dan pegawai di sekolah publik dan pengadilan memakai simbol-simbol keagamaan. Ide netral dari simbol-simbol keagamaan di ruang publik dan bebas di ruang privat ini terlihat tidak masuk akal bagi muslimah yang menganggap jilbab sebagai kebutuhan di ruang publik. ${ }^{37}$ Problem jilbab juga dialami oleh banyak Muslimah di Jerman dan Uni Eropa secara umum yang ingin mendapatkan pekerjaan atau menyewa apartemen. ${ }^{38}$

\footnotetext{
35 ICG, Islam and Identity, 8.

${ }^{36}$ https://www.hrw.org/news/2009/02/26/germany-headscarf-bans-violate-rights (diakses pada 21 maret 2017).

37 Esra Ozyurek, Being German Becoming Muslim: Race, Religion, and Conversyion in the New Europe (New Jersey: Princeton University, 2014), hlm. 12.

${ }^{38}$ Julia Pascoet, European Network Against Racism (ENAR) Policy Officer, in a public lecture at UIN 


\section{ARTIKEL}

E-ISSN: $2615-5028$

Selain itu, sejumlah isu yang menjadi tantangan bagi Muslim di Jerman dan seringkali menyulitkan integrasi mereka adalah pembatasan kewarganegaraan, tingkat pendidikan yang rendah mengakibatkan kesulitan akses pekerjaan di sektor publik, Kebijakan yang tidak seragam tentang pemakaian simbol agama, jilbab, dan undangundang perlindungan binatang yang menghalangi Muslim menyembelih hewan dan Qurban.

Di ranah politik, Islam belum diperlakukan setara dengan agama lain. Sampai saat ini, semua negara bagian di Jerman masih belum memberi ijin Islam untuk menjadi badan korporasi (public law corporate body), meskipun sudah beberapa kali mengajukan diri. $^{39}$ Beberapa komunitas keagamaan seperti Protestan, Katolik, Kristen Yunani Ortodoks, dan Yahudi telah menikmati status sebagai badan korporasi ini sehingga masing-masing dari mereka berhak mendapatkan bantuan dari pemerintah seperti pajak gereja (church tax), membuka kelas-kelas agama di sekolah publik, dan bantuan dalam pembangunan tempat ibadah. ${ }^{40}$

Belum diakuinya Islam sebagai bagian dari badan korporasi menjadi dilema tersendiri bagi negara Jerman. Di satu sisi, Jerman menghendaki adanya integrasi Muslim di negara tersebut, namun di sisi yang lain pemerintah Jerman tidak atau belum mau mengakui Islam sebagai bagian dari badan korporasi. Pengakuan ini sebenarnya menjadi salah satu hal yang penting bagi Jerman untuk memudahkan proses integrasi tersebut. Dengan tidak diakuinya Islam sebagai bagian dari badan korporasi, umat Islam di Jerman kurang mendapatkan perhatian dari pemerintah. Hal ini berbeda dengan Katolik, Protestan, dan Yahudi di mana masing-masing

Yogyakarta on 16 January 2014.

${ }^{39}$ ICG, Islam and Identity, 8.

${ }^{40}$ ICG, Islam and Identity, 8. 
komunitas ini mendapatkan pajak keagamaan (Religious Taxes/Kirchensteuer and Kultusstener respectively) setiap tahunnya. Gereja Katolik, sebagai contoh, mendapatkan bantuan kurang lebih 5,5 Milyar Euro per tahun untuk pajak keagamaan saja. Adapun umat Islam hanya mendapatkan seperlima dari jumlah tersebut atau sekitar 1 milyar Euro per tahun. ${ }^{41}$ Artinya, sampai saat ini umat Islam di Jerman masih diperlakukan secara berbeda dan tidak mendapatkan keistimewaan sebagaimana komunitas agama yang telah diakui sebagai bagian dari badan korporasi.

Meskipun secara teritis umat Islam di Jerman hidup di negara sekuler, dalam praktiknya hanya lonceng gereja saja yang diperkenankan untuk didengarkan di ruang publik. Umat Islam dilarang untuk mengumandangkan suara azan baik untuk salat lima waktu, salat Jumat, maupun acara-acara pada hari besar umat Islam. ${ }^{42}$ Selain itu, umat Islam juga tidak mendapatkan hak untuk tampil di media penyiaran seperti televisi dan radio Jerman meskipun mereka membayar untuk penyiaran layanan publik (public-service broadcasting). ${ }^{43}$

Dalam bidang pendidikan, sekitar 700.000 Muslim Jerman belajar di sekolah dan pendidikan Tinggi. Akan tetapi, berdasarkan penelitian terbaru, anak-anak imigran Muslim ditempatkan di sekolah yang lebih rendah karena tak sanggup mengikuti divisi sekolah yang paling tinggi. Tingkat pendidikan Muslim di Jerman sendiri berskala tinggi sebanyak $5 \%$, sedang $25 \%$, dan rendah $71 \%{ }^{44}$ Berdasarkan data dari Badan Pusat Arsip Islam di Jerman sebagaimana dikutip Euro Muslim diketahui bahwa kurang lebih 20\% dari seluruh anak-anak di sekolah Islam mengikuti

${ }^{41}$ Armin Langer, "Blocked Integration" dalam http://en.qantara.de/content/muslims-in-germanyblocked-integration (diakses 26 Maret 2015)

${ }^{42}$ Langer, "Blocked Integration"

${ }^{43}$ Langer, "Blocked Integration"

${ }^{44}$ Langer, "Blocked Integration" 
pengajaran Al-Quran. Secara umum, para guru agama Islam di Jerman kurang menguasai bahasa Jerman sebagai bahasa pengantar dalam memberikan materi keislaman, meskipun sudah berdiri beberapa lembaga pendidikan bagi para guru agama dan imam.

Saat ini, beberapa universitas telah menetapkan program pelatihan guru Islam, meski mendapatkan banyak kritikan. Pada tahun 2005 Universitas Munster mulai menyelenggarakan pendidikan bagi guru-guru agama Islam. Hal serupa juga diselenggarakan oleh Universitas Osnabruck pada tahun 2007 dengan memulai program pendidikan Imam, disusul Universitas Erlangen-Nürnberg pada 2011. Munich dan Frankfurt juga sudah menawarkan pendidikan kewarganegaraan bagi para Imam atau pemimpin agama Islam. Dorongan lebih jauh terkait pendidikan Imam secara profesional terhalang masalah pendanaan dan organisasi penyelenggara. Meski mendapat tantangan yang besar, komunitas Muslim Alawiyah (Alevis) telah sukses menjalankan program pendidikan di Jerman bagi kelompok mereka, disusul keberhasilan komunitas Muslim Turki meski dalam skala lebih kecil. ${ }^{45}$

Dalam bidang politik, partisipasi Muslim di parlemen Jerman cukup tinggi. Pada masa jabatan 2009-2013 tercatat sekitar 20-an Muslim yang duduk di parlemen yang sebagian besar dari mereka berasal dari keturunan Turki, Arab, dan Iran. Partai politik yang menjadi kendaraan mereka untuk duduk di Parlemen di antaranya adalah Social Democratic Party (SDP), Christian Union Party (CPU) dan Green Party. ${ }^{46}$ Namun demikian, kehadiran mereka di parlemen tidak merepresentasikan aspirasi Muslim di Jerman. Bahkan, sebagian besar dari mereka, meski berlatarbelakang keluarga

${ }^{45}$ Mathias Rohe, "Germany", dalam Jorgen Nielsen (ed.) Yearbook of Muslims in Europe, Vol.2 (Leiden: Brill, 2010), 224.

${ }^{46}$ http://www.euro-islam.info/country-profiles/germany/, (diakses 28 Maret 2015) 


\section{ARTIKEL}

E-ISSN: $2615-5028$

Muslim, tidak mencerminkan sebagai seorang Muslim. Mereka sudah terbiasa mengonsumsi alkohol, daging babi, dan kebiasaan masyarakat Barat pada umumnya.

Pada sektor rumah hunian, imigran muslim umumnya tinggal di rumah sewa penuh sesak, miskin fasilitas, dan biaya sewa yang mahal. Segregasi spasial ini menimbulkan konsentrasi-konsentrasi Muslim yang membentuk pusat-pusat etnik di perkotaan. Hal ini menjadi perhatian tersendiri bagi pemerintah Jerman untuk mengurangi konsentrasi imigran Muslim di daerah-daerah tertentu. Akan tetapi, organisasi muslim Türkische Gemeinde Deutschland (Komunitas Turki di Jerman, TGD), menyatakan kebijakan tersebut harus diikuti relokasi yang lebih layak di bidang pendidikan, akomodasi, dan aspek sosial lainnya. Perkembangan terakhir berubah lebih positif, bahwa pemerintah Jerman telah menginstruksikan perbaikan peralatan dan renovasi apartemen. ${ }^{47}$

Bentuk diskriminasi lain yang dihadapi Muslim di Jerman di hadapi di tempat kerja, khususnya bagi pekerja buruh Muslim. Di sejumlah tempat kerja mereka kesulitan untuk melaksanakan ibadah harian seperti salat Jumat, salat 5 waktu, dan juga di kantin yang tidak menyediakan makanan berlabel halal bagi mereka. Para Muslimah juga mendapatkan perlakuan diskriminatif karena jilbab yang mereka kenakan. ${ }^{48}$

\section{Integrasi dan Tantangan Radikalisme}

Sejak tahun 2006, para politisi dan pembuat kebijakan di negara Jerman telah memulai langkah untuk melakukan integrasi sosial antara umat Islam dengan budaya

\footnotetext{
${ }^{47}$ Ibid.

${ }^{48}$ Ibid.
} 
Jerman. Mereka menyadari bahwa tidak hanya Islam ekstremis yang harus dikontrol, tetapi juga gerakan anti-Islam yang berkembang di Jerman harus diawasi. Menteri Dalam Negeri Jerman, Wolfgang Schauble, pada tahun 2006 menyelenggarakan Konferensi Islam German untuk membangun dialog antara Negara Jerman dan Muslim yang berada di negara tersebut. Dalam pembukaan konferensi tersebut dia menyatakan bahwa Islam adalah bagian dari Jerman dan Eropa. Islam adalah bagian dari masa lalu dan masa depan Jerman. Pada saat yang sama Kanselir Angela Merkel berinisiatif menyelenggarakan konferensi tentang Integrasi untuk mengeksplorasi konsep baru bagaimana menyikapi perbedaan sebagai bagian dari proses perubahan di Jerman. ${ }^{49}$

Pergeseran sudut pandang atau paradigma dalam melihat Islam ini terkait erat dengan kebutuhan Jerman terhadap tenaga kerja imigran. Seperti yang sudah dijelaskan pada bagian sebelumnya bahwa pertumbuhan ekonomi Jerman tidak lepas dari SDM yang didatangkan dari negara lain. Dengan kebijakan integrasi ini diharapkan Jerman menjadi tempat yang nyaman bagi para imigran untuk tetap menjaga kestabilan ekonomi negara tersebut. ${ }^{50}$

Sejak peristiwa Bom WTC 11 September 2001, dan diikuti dengan pernyataan pemerintah Amerika untuk memerangi “terorisme global”, persepsi tentang Muslim sebagai teroris juga menjadi wacana di negara-negara Eropa termasuk Jerman. Gejala Islamofobia ini juga menjadi salah satu sebab berbagai tindakan diskriminasi yang dialamatkan kepada penduduk Muslim. Berdasarkan penelitian yang dilakukan oleh Partai Sosial-Demokratic bekerja sama dengan Friedrich Ebert Fondation yang

49 Nayka Foroutan, Identity and Muslim Integration in Germany (Washington DC: Migration Policy Institute, 2013), hlm. 7.

${ }^{50}$ Foroutan, Identity and Muslim, 7. 
berjudul Intolerance, Prejudice, and Discrimination: A European Report (2011) menyatakan bahwa hampir separuh (46,1\%) warga Jerman mengatakan bahwa terlalu banyak orang Islam di Jerman, meski hanya 5\% mereka (Muslim) sangat berpengaruh $(54,1 \%)$ dan agama mereka tidak toleran $(52,2 \%) .{ }^{51}$

Sebagian dari warga negara Jerman yang tidak senang terhadap kehadiran Muslim di negara tersebut kemudian membentuk beberapa gerakan menentang Muslim, salah satunya dan yang terkenal yaitu gerakan Patriotic Europeans Against the Islamization of the Occident (PEGIDA). Pada awal tahun 2015, sekitar 18.000 warga Jerman yang bergabung dalam Pegida melakukan aksi demonstrasi di Dresden, ibu kota negara bagian Saxony (Sachsen), memprotes fanatisme agama dan radikalisme Islam di Jerman. Salah satu alasan dari aksi unjuk rasa ini adalah hasil jajak pendapat yang dilakukan oleh majalah Stern yang menyatakan bahwa 30\% dari warga Jerman berpikir bahwa Islam telah berpengaruh besar dalam kehidupan masyarakat Jerman. ${ }^{52}$ Aksi ini bukanlah yang pertama kali dilakukan oleh kelompok Pegida. Sebelumnya, pada bulan Desember 2014, sekitar 10.000 simpatisan Pegida juga melakukan aksi yang sama. Di samping alasan semakin menguatnya Islam di Jerman, mereka juga menolak kebijakan pemerintah Jerman yang dikenal liberal mengenai masalah imigrasi. Sementara itu, di sejumlah kota lainnya seperti di Berlin, Hamburg, Koln, dan Stutgart sekitar 22.000 orang melakukan aksi menentang kelompok Pegida. Tabloid Bild dalam halaman utamanya juga memuat berita utama yang bertajuk “Tidak untuk Pegida." 53

\footnotetext{
${ }^{51}$ Foroutan, Identity and Muslim, 6.

52 Harian Kompas, 7 Januari 2015.

${ }^{53}$ Ibid.
} 


\section{ARTIKEL}

E-ISSN: $2615-5028$

Gerakan demonstrasi dari kelompok Pegida tersebut kembali meramaikan wacana tentang kehadiran Islam di Jerman yang sebagian besar dianut oleh para imigran. Pada tahun 2014, jumlah imigran yang datang ke negara ini melonjak sampai 200.000 orang, empat kali lipat dibandingkan tahun 2012 yang sebagian besar berasal dari Turki dan kawasan Timur Tengah. ${ }^{54}$

Kebijakan integrasi pemerintah Jerman menghendaki adanya asimilasi budaya dari beragam budaya yang terdapat di Jerman untuk melebur menjadi budaya Jerman. Hal ini menjadi tantangan tersendiri bagi umat Islam di Jerman di mana mereka memiliki tradisi budaya yang dalam beberapa hal bertentangan dengan budaya Jerman dan masyarakat Barat pada umumnya. Sebab dalam asimilasi, biasanya yang minoritas itu yang akan terhilangkan identitasnya. ${ }^{55}$ Namun demikian, kebijakan asimilasi ini dianggap sebagai solusi setelah program multikulturalisme dianggap tidak lagi mencukupi sebagai solusi perkembangan masyarakat Jerman.

Sebagai konsekuensinya, sejumlah kecil Muslim di Jerman yang ingin tetap dapat mentradisikan budaya Islamnya mengalami sejumlah kendala. Keinginan sebagian umat Islam untuk membangun masyarakat islami atau mencita-citakan kehidupan yang bernafaskan ajaran Islam disebut dengan Islamist. Crisis Group (2007) mencatat bahwa hanya sebagian kecil, yaitu 1\% dari Muslim di Jerman berideologi islamist. Beberapa indikasi yang menjadi ukuran dari pembagian ini di antaranya adalah keterkaitan dengan jaringan Islam al-Qaeda di Timur Tengah, keinginan untuk mendirikan khilafah Islamiyah, serta memiliki hubungan dengan gerakan Ikhwanul

\footnotetext{
${ }^{54}$ Ibid.

${ }^{55}$ Rahman, M. Taufiq. Glosari Teori Sosial. Bandung: Ibnu Sina Press. 2011, h. 8. 


\section{ARTIKEL}

Muslimin di Mesir dan sejumlah negara Islam lainnya. IGMG dianggap sebagai salah satu organisasi yang menyerukan ide-ide Islamist di Jerman. ${ }^{56}$

Kondisi di atas diperburuk dengan semakin menyebarnya paham ultrakonservatif seperti ideologi ISIS. Semakin banyaknya migran Muslim dari Timur Tengah (Wahhabi-salafi) dan juga semakin terbukanya informasi global semakin membuka penyebaran ideologi ultra-konservatif dan bahkan radikal di Jerman. Walaupun kondisi sosial-politik di Jerman jauh lebih lebih kondusif dibandingkan dengan Francis dan Belgia, radikalisme Islam juga terjadi di beberapa tahun terakhir.

\section{Kesimpulan}

Islam merupakan bagian dari sejarah Jerman. Secara historis Islam telah menorehkan banyak perannya dalam sejarah Jerman sejak masa Turki Usmani dan Kerajaan Prussia. Terlepas dari pro-kontra banyak pihak di Jerman, keberadaan Muslim di Jerman bukan hanya sejak tahun 1960-an. Berbagai etnis Muslim di Jerman seperti Turki dan beberapa etnis Eropa Timur telah memberikan bukti yang jelas kontribusi mereka dalam pembentukan negara-bangsa Jerman. Islam di Jerman mengalami dinamika dan tantangan yang cukup signifikan seiring dengan merebaknya Islamisme dan islamofobia di dunia.

Islam mengalami tantangan yang signifikan di Jerman. Seiring dengan perkembangan Islam secara global, Islam di Jerman juga mengalami perkembangan signifikan baik di segi kuantitatif maupun kualitatif. Fenomena ini ditengarai dengan munculnya berbagai organisasi Islam di Jerman dari berbagai etnis. Fenomena lain adalah jumlah masjid yang secara kuantitatif juga terus bertambah di beberapa kota

${ }^{56}$ Crisis Group Europe Report: Islam and Modernity in Germany..., hlm. 17-18. 
besar. Terakhir, masuknya beberapa Muslim di ranah politik juga merupakan bentuk integrasi Muslim ke dalam budaya Eropa. Di sisi lain, kehadiran Muslim juga menyebabkan munculnya gerakan anti-pendatang Muslim seperti Pegida (Patriotische Europaer Gegen die Islamisierung des Abenlandes/ Orang Eropa Patriotik Melawan Islamisasi Barat). Walaupun gerakan Pegida tidak besar, beberapa aktivitasnya cukup vokal sehingga berkembang di beberapa kota besar di Jerman. Namun demikian, gerakan Pegida lebih merupakan reaksi karena banyaknya imigran Muslim dari berbagai negara Muslim di Timur Tengah dan Afrika. Di kalangan Muslim bahkan ada juga beberapa fenomena Islamisme seperti kekerasan terhadap non-Muslim di ruang publik dan juga bergabungnya beberapa orang ke wilayah konflik ke Syria.

Islam dan Muslim di Jerman mempunyai masa depan yang bagus. Respons publik maupun pemerintah Jerman cukup bagus sehingga Islam mempunyai prospek yang bagus. Tantangan Muslim di Jerman yang paling besar bukan dari luar atau bersifat eksternal, tapi justru internal, yaitu sejauh mana Muslim di Jerman mampu untuk berintegrasi dengan budaya di Eropa. Semakin banyak Muslim di Jerman mampu berintegrasi, semakin bagus dan semakin sedikit masalah Muslim secara eksternal. Diantara integrasi Muslim di Jerman adalah penguasaan bahasa Jerman dan budaya Eropa lainnya sejauh tidak bertentangan dengan norma-norma Islam. Proses ini, lambat-laun akan menghasilkan corak Islam Eropa yang bisa jadi berbeda dengan karakter Islam di Timur Tengah yang akan lebih mewarnai Eropa secara lebih luas.

\section{DAFTAR PUSTAKA}


Ahmad, Fauzia, dan Siddique Seddon (ed.), Muslim Youth: Challenges, Oppotunuties, and Expectacions. London: Continuum, 1998.

Davidson, Emma, Rosalind Edwards, Lynn Jamieson, and Susie Weller. "Big data, qualitative style: a breadth-and-depth method for working with large amounts of secondary qualitative data." Quality \& Quantity 53, no. 1 (2019): 363-376.

Fetzer, Joel S \& Soper, J. Christopher. Muslims and the State in Britain, France and Germany. Cambridge University Press: Cambridge. 2005.

Fink, Arlene. Conducting research literature reviews: from the Internet to paper. Sage Publications, 2019.

Foroutan, Nayka. Identity and Muslim Integration in Germany. Washington DC: Migration Policy Institute, 2013.

Grims, Brian J. \& Mehtab S. Karim, The Future of the Global Muslim Population: Projections for 2010-2030. Washington: Pew Research Center, 2011.

Harian Kompas, 7 Januari 2015.

International Crisis Group, Europe Report $\mathrm{N}^{0} 181$, Islam and Identity in Germany. 14 Maret 2007.

International Religious Freedom Report: Germany 2012. US State Department: Bureau of Democracy, Human Rights, and Labor. 2012.

Kettani, Houssain, Muslim Population in Europe: 1950 - 2020 dalam International Journal of Environmental Science and Development, Vol. 1, No. 2, June 2010. 


\section{ARTIKEL}

E-ISSN: $2615-5028$

Kettani, M. Ali, Minoritas Muslim di Dunia Dewasa Ini, Jakarta: PT Raja Grafindo Persada.

Maryam, Siti, dkk. Sejarah Peradaban Islam dari Masa Klasik Hingga Modern, Yogyakarta: LESFI, 2009.

Mathias Rohe, "Germany" dalam Jorgen Nielse (ed), Yearbook of Muslims in Europe, Vol.2. Leiden: Brill, 2010.

Ozyurek, Esra, Being German Becoming Muslim: Race, Religion, and Conversyion in the New Europe. New Jersey: Princton University, 2014.

Pew Research Center, The Future Global Muslim Population: Projections for 2010-2030, hlm. 121. Diakses dari http://www.pewforum.org/2011/01/27/the-futureof-the-global-Muslim-population

Rahman, M. Taufiq. Glosari Teori Sosial. Bandung: Ibnu Sina Press. 2011.

Salganik, Matthew J. Bit by bit: social research in the digital age. Princeton University Press, 2019.

Statistisches Bundesamt (Destatis), 2017. (diakses 7 Maret 2019).

\section{Website:}

http://en.qantara.de/content/muslims-in-germany-blocked-integration

http://www.euro-islam.info/country-profiles/germany/

http://www.nationsonline.org/oneworld/germany.htm

http://www.pewresearch.org/fact-tank/2016/07/19/5-facts-about-the-muslim-

$$
\text { population-in-europe/ }
$$




\section{ARTIKEL}

E-ISSN: 2615-5028

http://www.worldpopulationstatistics.com/germany-population/

https://rp-online.de/nrw/panorama/nrw-salafisten-agitieren-in-55-moscheen aid$\underline{18340503}$

https://www.dw.com/en/merkel-islam-is-a-part-of-germany/av-43067794

https://www.gatestoneinstitute.org/6793/germany-20-million-muslims 